Martinez, M. T., A. M. Long, H. A. Mathewson, and M. L. Morrison. 2019. Broad-scale habitat use by fledgling Black-capped Vireo. Avian Conservation and Ecology 14(1):5. https://doi.org/10.5751/ACE-01300-140105

Copyright (C) 2019 by the author(s). Published here under license by the Resilience Alliance.

Research Paper

\title{
Broad-scale habitat use by fledgling Black-capped Vireo
}

\author{
Marisa T. Martinez ${ }^{1,2}$, Ashley M. Long ${ }^{3,4}$, Heather A. Mathewson ${ }^{4,5}$ and Michael L. Morrison ${ }^{2}$ \\ ${ }^{1}$ Department of Biological Sciences, Florida Atlantic University, ${ }^{2}$ Department of Wildlife and Fisheries Sciences, Texas A\&M \\ University, ${ }^{3}$ Louisiana State University, ${ }^{4}$ Texas A\&M Institute of Renewable Natural Resources, ${ }^{5}$ Tarleton State University
}

\begin{abstract}
Knowledge of avian habitat associations during the postfledging stage is lacking for most songbirds, which limits the ability to develop and implement management plans that address the full life cycle of birds. The Black-capped Vireo (Vireo atricapilla; hereafter vireo) is a Neotropical migratory songbird that breeds in early to mid-successional vegetation but has been documented using late-successional vegetation. We used data collected in 2013 and 2014 to determine the spatial distribution of vireo fledglings in relation to the availability of woodland cover in central Texas. We found that woodland cover was used less often than it was available in the landscape. We used a model selection approach with generalized linear mixed models and generalized additive mixed models to determine which variables, i.e., age (days since fledging) or season (days since the first nest at the study site fledged young), best explained vireo fledgling use of woodland and distance from fledgling locations to woodland. The probability of woodland use by fledglings was best predicted by season, and fledglings were located closer to woodland vegetation as the season progressed and as fledglings aged. The lack of selection for woodland cover by vireo fledglings and their persistent use of shrub-dominated cover suggest that the shrubdominated cover provides analogous resources to those used by adults during the breeding season. Fledglings also use woodland cover where available and move toward the shrubland-woodland interface over time, suggestive of a possible function of woodland vegetation as postfledging habitat. Thus, land managers should consider the impact of land management practices in woodland and shrubland cover on the habitat availability for Black-capped Vireo throughout its life cycle, and on other migratory species.
\end{abstract}

\section{Utilisation à grande échelle de l'habitat par les oisillons deViréo à tête noire}

RÉSUMÉ. Les connaissances sur les associations d'habitats utilisés après l'envol du nid sont insuffisantes pour la plupart des oiseaux chanteurs, ce qui limite la capacité d'élaborer et de mettre en oeuvre des plans de gestion qui tiennent compte du cycle de vie complet des oiseaux. Le Viréo à tête noire (Vireo atricapilla; ci-après viréo) est un oiseau chanteur migrateur néotropical qui se reproduit dans la végétation de début à milieu de succession, mais dont la présence a été documentée dans la végétation de fin de succession. Nous avons utilisé les données collectées en 2013 et 2014 pour déterminer la distribution spatiale des oisillons de Viréo par rapport à la disponibilité du couvert forestier dans le centre du Texas. Nous avons constaté que le couvert forestier était moins utilisé que ce qui était disponible dans le paysage. Nous avons utilisé une approche de sélection de modèle avec des modèles mixtes linéaires généralisés et des modèles mixtes additifs généralisés pour déterminer quelles variables, c.-à-d. l'âge (jours depuis l'envol) ou la saison (jours depuis l'envol du premier nid sur le site étudié), expliquent le mieux l'utilisation des forêts par les oisillons Viréos et la distance entre les oisillons et les forêts. La probabilité de l'utilisation des forêts par les oisillons était mieux prédite par la saison, et les oisillons étaient situés plus près des forêts à mesure que la saison avançait et que les oisillons vieillissaient. L'absence de sélection de la couverture forestière par les oisillons Viréos et leur utilisation persistante d'une couverture dominée par des arbustes suggèrent que cette dernière fournit des ressources analogues à celles utilisées par les adultes pendant la saison de reproduction. Les oisillons utilisent également la couverture forestière, quand elle est disponible, et se déplacent progressivement vers l'interface buisson-forêt, suggérant une possible utilisation de la forêt en tant qu'habitat après le premier envol. Par conséquent, les gestionnaires des terres devraient prendre en compte l'impact des pratiques de gestion des terres dans la couverture forestière et arbustive sur la disponibilité de l'habitat pour les Viréos à tête noire tout au long de son cycle de vie ainsi que sur d'autres espèces migratrices.

Key Words: Black-capped Vireo; habitat use; juvenile; migratory songbird; postfledging; Vireo atricapilla

\section{INTRODUCTION}

Compared to the adult lifestage, knowledge of avian habitat use during the juvenile lifestage, particularly the period between fledging and migration, is lacking for most songbirds (Anders et al. 1998, Streby and Andersen 2011, Walker 2015). This shortcoming is, in part, due to limitations in detecting young that behave more secretively after fledging (Anders et al. 1998). The young of some species also disperse far from their natal areas in the first several weeks after fledging, making it difficult to relocate young birds (Anders et al. 1998). Data from studies that have addressed habitat use during the postfledging period suggest that some young songbirds use different vegetation types than do breeding adults. For example, juvenile Wood Thrush (Hylocichla mustelina) in Missouri (Anders et al. 1998) and Virginia (Vega Rivera et al. 1998) disperse from their mature oak-hickory (Quercus-Carya) forest nesting area and move into early successional vegetation during the postfledging period. Such differential habitat use between age classes may reflect predator 
avoidance or foraging opportunities during a fledgling's transition to self-sufficiency (Moore et al. 1993). Understanding habitat use by juvenile birds could uncover resources that have potential importance for a species, which may have otherwise been unnoticed or disregarded (White et al. 2005, Vitz and Rodewald 2007, Streby and Andersen 2013), and could assist with the development of management plans that address the full life cycle of birds.

The Black-capped Vireo (Vireo atricapilla; hereafter vireo) is a Neotropical migratory songbird that breeds in Oklahoma, Texas, and northern Mexico (Grzybowski 1995). Adult vireos typically select shrublands with $30-45 \%$ deciduous cover and 36-55\% woody cover characterized by scrubby shrubs of irregular height and trees $<2 \mathrm{~m}$ in height for nesting (Grzybowski 1995). Young vireos rely on their parents for food and tend to remain within the natal territory during the first few weeks postfledging (Graber 1961). Once independent, juveniles select for shrubland vegetation over forest and grass vegetation (Dittmar et al. 2014) and forage in shrubs and trees $<3 \mathrm{~m}$ in height (Houston 2008). However, observations from various sites across the breeding range in central Texas indicate that independent vireo fledglings may disperse out of their territories into woodlands (Houston 2008, Pope et al.2013), shaded ravines (Graber 1961), and riparian forests (Dittmar et al. 2014) during the postfledging period. Additionally, as juvenile vireos age, they become less vulnerable to predation than younger fledglings and occupy a wider array of vegetation conditions while foraging (Walker 2015).

We used data collected in 2013 and 2014 to examine how time of season and fledgling age influence fledging use of and distance to woodland cover. Prior research in our study area suggests that arthropod abundance and biomass decline within vireo breeding habitat as the breeding season progresses (Morgan 2012). Woodlands may supply vireo fledglings with a perpetual abundance of prey (Dittmar et al. 2014) and protective cover from predators and heat during the later stages of summer (e.g., Brokaw and Lent 1999). As such, we predicted that vireo fledgling use of woodland cover would increase, and distance from vireo detections to woodland would decrease, over time and as fledglings age.

\section{METHODS}

\section{Study sites}

We conducted our study at the Balcones Canyonlands National Wildlife Refuge and surrounding private properties across Burnet, Travis, and Williamson counties in central Texas, USA. The Ecological Systems Classification and Mapping Project identifies the area as Edwards Plateau limestone savanna and woodland (Elliot et al. 2014). The predominant land-cover types are shrubland, limestone woodland, dry-mesic slope woodland, riparian forest, and grassland. Steep canyons characterize the topography of the area, with broad plateaus primarily composed of limestone bedrock (Sellards et al. 1933). The canopy layer is predominantly Ashe juniper (Juniperus asheii), with subdominant species of broadleaf hardwood such as Texas red oak (Quercus buckleyi), plateau live oak (Q. virginiana var. fusiformis), and escarpment black cherry (Prunus serotina var. exima; Gehlbach 1988, Diamond 1997). The understory primarily consists of shin oak ( $Q$. havardii) mixed with other species such as greenbrier
(Smilax spp.), prickly pear (Opuntia spp.), elbowbush (Forestiera pubescens), and cedar elm (Ulmus crassifolia). We established nine study sites on five Balcones Canyonlands National Wildlife Refuge tracts and four private properties. The area of the study sites ranged from 63-275 ha (mean \pm SD: $161 \pm 77$ ha). We selected sites that represented a continuum of woody vegetative cover (i.e., grassland, shrubland, and forest) to obtain variation in the availability of land-cover types.

The study area is classified as subhumid and has a mean annual precipitation of $60 \mathrm{~cm}$, with an accumulation of approximately $39.5 \mathrm{~cm}$ between March and July, during the vireo breeding season. The accumulation of precipitation from March-July was average in 2013 at $39.5 \mathrm{~cm}$ and below average in 2014 at $21.6 \mathrm{~cm}$. Mean annual temperature in this region is $18.5^{\circ} \mathrm{C}$, with an average of $22.4^{\circ} \mathrm{C}$ from March-July. Mean temperatures were average during these months in 2013 and 2014 at $22.9^{\circ} \mathrm{C}$ and $22.7^{\circ} \mathrm{C}$, respectively (National Climate Data Center 2014).

\section{Territory and nest monitoring}

We conducted transect surveys in March 2013 and 2014 during the early vireo breeding season to confirm vireo occupancy of the study sites. We created a grid network of points with $200 \times$ $200 \mathrm{~m}$ spacing originating from a random starting point, across the entirety of each study site, including woodland cover. We walked from point to point along a transect at a $1 \mathrm{~km} / \mathrm{h}$ pace from sunrise to 13:00 and marked locations of singing male vireos using a Garmin Rino 130 handheld global positioning system (GPS). We repeated transect surveys at each study site 23 times/wk for 1-2 wk, after which we visited the locations of male vireos every 3-5 d during the breeding season (March-July) to delineate the spatial extent of each territory. During each visit, we marked vireo locations every $2 \mathrm{~min}$, recording up to 30 points over $1 \mathrm{~h}$ (Barg et al. 2005). If a singing male was present in an area for $>4 \mathrm{wk}$, we defined that area as an established territory, and we assumed that each territory represented an individual male. We assigned a unique territory code to each established territory.

While territory mapping, we searched for nests using adult behavioral cues (e.g., alarm calls, carrying nest material, carrying food, males singing on the nest). Once we located a nest, we checked it every 2-3 d until the nest failed or fledged. We banded nestlings with one U.S. Geological Survey aluminum band anodized red to identify birds banded by Texas A\&M University, and a unique combination of plastic color bands to assist in identification and aging. In addition, we target mist-netted and banded adults to assist in family group identification. When a nest failed, we monitored the territory for another nesting attempt. If the nest fledged, we began fledgling monitoring in the territory. Our research activities involving animal observation, handling, and banding were approved by the Texas A\&M University Animal Use and Care Committee (protocol 2012-092), the U.S. Fish and Wildlife Service (Federal Fish and Wildlife Permit 195248), and the U.S. Geological Survey (Federal Bird Banding Permit 21755).

\section{Fledgling monitoring}

To determine the spatial distribution of fledglings, we conducted territory and transect surveys across the entirety of each study site. We initiated territory surveys when $\geq 1$ vireo fledgling 
fledged from a monitored nest. We approached the nest area every 3-5 $\mathrm{d}$ and searched for fledglings using visual or audio cues from the parent (e.g., food carries, vocalizations) or young (e.g., begging calls). We initiated transect surveys approximately $3 \mathrm{wk}$ after the first monitored nest fledged to detect young that left the natal territory or fledged from undetected nests. We walked the same transects used in the early breeding season and extended transects to include a 300-m buffer around the study site. We used $300 \mathrm{~m}$ as a conservative buffer based on the mean distance juvenile vireos move between consecutive locations (Dittmar et al. 2014). We walked transects every 3-5 d from sunrise to 13:00. To minimize time-of-day effects, we varied the order and direction of transect surveys. To minimize differences in detectability due to fledging age, survey date, and land-cover type, we walked transects at a slow pace of $1 \mathrm{~km} / \mathrm{h}$ and walked all transects to ensure full coverage of the study area, which included all available vegetation types. We alternated between territory surveys and transect surveys at sites to locate fledglings every $2-3 \mathrm{~d}$.

When we detected a nonbanded or banded fledgling, we recorded its location and the sex and age (hatch year or after hatch year) of conspecifics present. If the fledgling was banded, we resighted its color band combination with binoculars for identification and aging. We also attempted to resight color bands of banded conspecifics present. After a 10-min observation period, we walked to the next territory or returned to the transect, and searched for vireos that had fledged from another territory.

\section{Landscape assessment}

We used 2012 National Agriculture Imagery Program (NAIP, 1$\mathrm{m}$ resolution) and ecological site descriptions collected by the $\mathrm{U}$. S. Department of Agriculture Natural Resources Conservation to assess the landscape cover of the study area. The years when these images and classifications were collected did not need to overlap the years of our study because the study area did not undergo considerable land-cover change from what we detected via 2012 NAIP imagery and on-the-ground observations. We used visual image interpretation of NAIP imagery (e.g., tone, texture, pattern, relationship to other objects) and surveys to identify land cover in the study area as either woodland or nonwoodland cover (Horning 2004). We defined woodland cover as contiguous vegetation of oak-juniper and deciduous forest, which included limestone woodland, dry-mesic slope woodland, and riparian forest cover types but excluded oak mottes within shrubdominated cover. Despite vireo fledgling selection for riparian vegetation (Dittmar et al. 2014), we aggregated riparian forest with other cover types because it comprised just $8 \%$ of the total woodland in the study area. Using ArcGIS 10.0 (ESRI 2010), we created a $300-\mathrm{m}$ buffer around the minimum convex polygon of all the fledgling locations at each study site, which defined the boundaries of what we considered to be available postfledging habitat.

For descriptive purposes, we calculated the percentage of available woodland cover for each study site by dividing the area of woodland cover by the total area of available habitat, including the $300-\mathrm{m}$ buffer. We projected fledgling GPS locations onto the land-cover map using ArcGIS and assigned each location to a woodland or nonwoodland cover type. We also measured the distance from each fledgling location to woodland using
Geospatial Modelling Environment 7.3.0 software (Spatial Ecology, LLC) and assigned a value of 0 to fledglings detected in woodland cover.

\section{Statistical analysis}

During our territory and transect surveys, we often found groups of juvenile vireos from the same brood in close proximity to one another. Thus, to avoid pseudoreplication, we only used location information recorded for the first fledgling detected during our 10-min observation period in our analyses. We considered the locations temporally independent because we acquired them at territories 2-3 d apart.

Based on the known ecology of the vireo, we made the assumption that the studied individuals are less likely to use woodland cover. To validate our assumption, we used a chi-square goodness-of-fit test in R (R Core Team 2018) to determine whether fledglings used woodland cover less than its availability in the study area (Neu et al. 1974, Cherry 1996). For this analysis, we used location information from nonbanded and banded fledglings that we obtained throughout the postfledging season.

We used a model selection approach and generalized linear mixed models (GLMMs, lme4 package for R; Bates et al. 2015) to determine which variables best explained vireo fledgling use of woodland and distance from vireo detections to woodland. Our candidate models, which represented our a priori hypotheses, included an intercept-only model, postfledgling age (days since fledging, hereafter age), time of postfledging season (days since the first nest at the study site fledged young, hereafter season), and the interaction between age and season (Table 1). Prior to model selection, we examined the correlation between age and season, which was significant but weak (Pearson correlation test, $\left.P<0.05, R^{2}=0.37\right)$. Thus, we retained the interaction in regression analyses for both vireo use of woodland and distance from vireo locations to woodland. GLMMs for vireo fledgling use of woodland included a logistic link function to account for binary data $(0=$ fledgling observed in nonwoodland vegetation, $1=$ fledging observed in woodland vegetation). All GLMMs included territory identification code as a random effect, which assigned the fledgling to its natal territory. Therefore, we only included location information for banded fledglings in the GLMMs.

We used the Akaike Information Criterion adjusted for small sample sizes $\left(\mathrm{AIC}_{\mathrm{c}}\right)$ to rank GLMMs, and we determined the relative support of each model using $\triangle \mathrm{AIC}_{\mathrm{c}}$ and Akaike weights ( $w_{\mathrm{i}}$; Sugiura 1978, Burnham and Anderson 2002). We considered models with $\Delta \mathrm{AIC}_{\mathrm{c}}<2.0$ equally plausible. We calculated McFadden's pseudo- $\mathrm{R}^{2}$ for the best fit logistic regression model and considered $\mathrm{R}^{2}>0.2$ a good fit (McFadden 1974). We verified the assumptions of linearity and homogeneity for our best fit GLMMs by visually inspecting the distribution of simulated residuals using the DHARMa package in R (Hartig 2018). When McFadden's pseudo- $\mathrm{R}^{2}$ suggested good fit and we verified our assumptions, we used the model to predict vireo fledgling use of woodland and distance from the vireo fledgling detection to woodland, and calculated the $95 \%$ confidence intervals (CIs) for each predicted vireo response. We then examined the extent of overlap among the $95 \%$ CIs to determine the potential statistical or biological significance of each relationship. 
Table 1. Model selection results for fledgling Black-capped Vireo (Vireo atricapilla) use of woodland cover and distance from the vireo fledgling detection to the nearest woodland at Balcones Canyonlands National Wildlife Refuge and surrounding private properties in 2013 and 2014.

\begin{tabular}{|c|c|c|c|c|c|c|c|}
\hline Response & Model $^{\dagger}$ & $\begin{array}{l}\text { Explanatory } \\
\text { variables }\end{array}$ & $\mathrm{K}^{\S}$ & Log-likelihood & $\mathrm{AIC}_{\mathrm{c}}^{\mathrm{l}}$ & $\Delta \mathrm{AIC}_{\mathrm{c}}^{\mathrm{f}}$ & $w_{\mathrm{i}}^{\#}$ \\
\hline \multirow[t]{5}{*}{ Woodland cover use } & \multirow[t]{5}{*}{ GLMM } & Season & 54 & -61.40 & 256.63 & 0.00 & 0.61 \\
\hline & & Season, Age & 55 & -61.08 & 259.05 & 2.43 & 0.18 \\
\hline & & Age & 54 & -63.02 & 259.87 & 3.24 & 0.12 \\
\hline & & Season $\times$ Age & 56 & -60.31 & 260.62 & 4.00 & 0.08 \\
\hline & & Null & 1 & -133.89 & 269.80 & 13.17 & 0.08 \\
\hline \multirow{10}{*}{ Distance to nearest woodland } & \multirow[t]{5}{*}{ GLMM } & Age & 50 & -1260.62 & 2645.88 & 0.00 & 0.55 \\
\hline & & Season & 50 & -1261.37 & 2647.38 & 1.49 & 0.26 \\
\hline & & Age, Season & 51 & -1260.59 & 2648.92 & 3.04 & 0.12 \\
\hline & & Age $\times$ Season & 52 & -1259.51 & 2649.90 & 4.02 & 0.07 \\
\hline & & Null & 2 & -1612.30 & 3228.65 & 582.76 & 0.00 \\
\hline & \multirow[t]{5}{*}{ GAMM } & Season & 50 & -1260.74 & 2647.40 & 0.00 & 0.50 \\
\hline & & Age & 53 & -1257.04 & 2648.20 & 0.89 & 0.32 \\
\hline & & Age $\times$ Season & 53 & -1258.02 & 2650.40 & 3.08 & 0.11 \\
\hline & & Age, Season & 54 & -1257.02 & 2651.40 & 4.02 & 0.07 \\
\hline & & Null & 2 & -1612.30 & 3228.60 & 581.29 & 0.00 \\
\hline
\end{tabular}

${ }^{\dagger}$ GLMM $=$ generalized linear mixed model, GAMM = generalized additive mixed model.

${ }^{\ddagger}$ Age $=$ days since fledging, Season $=$ days since the first nest at the study site fledged young, Null = null model.

${ }^{\S}$ Total number of parameters in model.

'Akaike information criterion corrected for small sample size.

${ }^{\top}$ AIC relative to the best-fit model.

"Model weight.

When we could not verify the assumptions for the GLMMs, we applied the same model selection procedure above using generalized additive mixed models (GAMMs; Zuur et al. 2013, Zuur 2016). GAMMs are an extension of generalized linear (mixed) models (Hastie and Tibshirani 1986, 1990) that have less strict assumptions regarding linearity and homogeneity between response and explanatory variables (Guisan et al. 2002). We used generalized cross-validation to determine the optimal amount of smoothing for the best fit models (Zuur 2016) using the mgcv package for R (Wood 2006), and we examined the extent of overlap among the $95 \%$ CIs for the predicted vireo response to determine the potential statistical or biological significance of each relationship.

\section{RESULTS}

The mean \pm SD woodland cover at the study sites was $46.3 \pm 26.8 \%$ (range $6-81 \%, N=9$ ), amounting to $60 \pm 41$ ha (range $7-147$ ha). We monitored 55 vireo territories and 78 vireo nests in 2013, and 45 vireo territories and 74 vireo nests in 2014. In 2013 and 2014, 68 and 71 of the nests were in shrubland, and 10 and 3 nests were in woodland, respectively. We banded 102 nestlings and 68 nestlings in 2013 and 2014, of which 71 and 68 fledged, respectively. In 2013, we acquired 276 fledgling locations, of which 166 were of 62 banded individuals. In 2014, we acquired 238 fledgling locations, of which 119 were of 41 banded individuals. Of the 514 total locations of fledglings, $16 \%$ occurred in woodland cover, which was less than expected based on the mean woodland availability in the study area $\left(\chi_{1}^{2}=184.47, P<0.01\right)$.

We used 285 locations of banded fledglings to determine which continuous variables for age and season best predicted vireo fledgling use of woodland. The GLMM that had season as the main effect was most parsimonious, had $\Delta \mathrm{AIC}_{\mathrm{c}}<2.0$, and had the highest $w_{\mathrm{i}}$ (Table 1). McFadden's pseudo- $\mathrm{R}^{2}$ was 0.54 , suggesting good fit, and we were able to verify assumptions of linearity and homogeneity. The predicted probability of woodland use by vireo fledglings increased from $\sim 10 \%$ to $\sim 25 \%$ over the course of the vireo postfledging season (Fig. 1).

Fig. 1. Predicted probability of woodland use by fledgling Black-capped Vireo (Vireo atricapilla) over the 2013 and 2014 postfledging seasons at Balcones Canyonlands National Wildlife Refuge and surrounding private properties. The relationship between predicted use of woodland and days of the postfledging season was determined using generalized linear mixed model selection. The prediction shows the increasing probability of woodland use from $\sim 10 \%$ on the first day to $\sim 25 \%$ on the last day of the postfledging season. Black line $=$ mean, gray $=95 \%$ confidence intervals.




We used 258 locations of banded fledglings to determine which age and season variables best predicted distance from vireo fledgling detections to woodland. We excluded 27 observations of fledglings that fledged from nests located in woodland. The GLMMs representing age and season had the same number of parameters, $\Delta \mathrm{AIC}<2.0$, and only slightly different $w_{\mathrm{i}}$ (Table 1 ). We thus considered them equally plausible models among the candidate models. The conditional $R^{2}$ (i.e., the variance explained by the entire model) for both main effects GLMMs was 0.92 . However, we were unable to verify the assumptions of linearity or homogeneity for either GLMM. Thus, we applied the same model selection procedure using GAMMs. Again, the models that contained age and season as main effects had the best fit based on parsimony and $\triangle \mathrm{AIC}_{\mathrm{c}}<2.0$ (Table 1). We thus considered them equally plausible models. Similar to the GLMMS, the conditional $R^{2}$ for both main effects GAMMs was 0.92 , but unlike the GLMMs, we were able to verify the assumptions of linearity or homogeneity for both models. For every 10 days postfledging and 10-d progression in the postfledging season, we predicted that vireo fledglings would be observed approximately $10 \mathrm{~m}$ closer to woodland cover (Figs. 2, 3).

Fig. 2. Predicted relationship between distance (m) of fledgling Black-capped Vireo (Vireo atricapilla) to woodland cover and day since fledging (age) during the 2013 and 2014 postfledging seasons at Balcones Canyonlands National Wildlife Refuge and surrounding private properties. The relationship was determined using generalized additive mixed model selection and predicts that fledglings are located $10 \mathrm{~m}$ closer to woodland for every 10 days postfledging. Black line $=$ mean, gray $=95 \%$ confidence intervals.

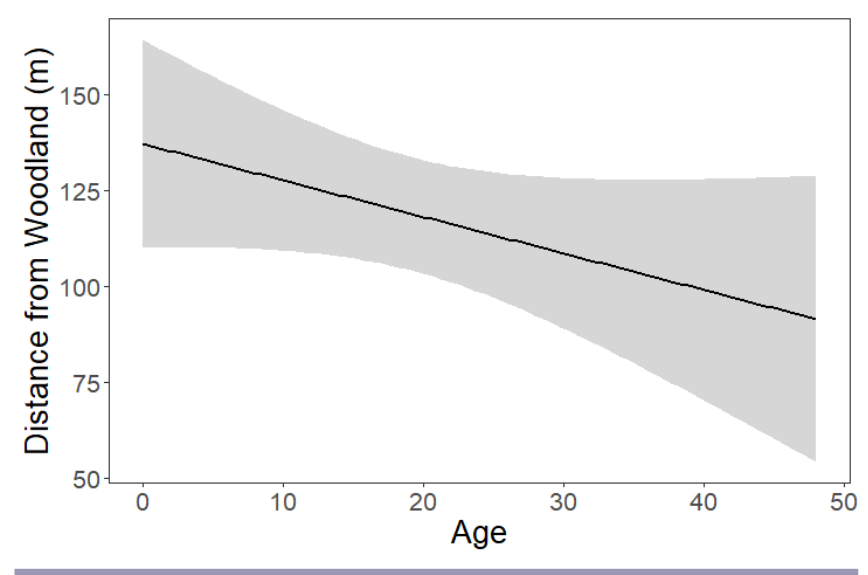

\section{DISCUSSION}

Vireo fledglings used woodland cover less than its availability in the landscape. Our finding supports that of Dittmar et al. (2014), who also observed that independent juveniles selected shrub vegetation preferrentially to forest vegetation. Using radio-tagged vireos, Walker (2015) found that older vireos (32-64 d postfledging) had home ranges with more shrubland and evergreen forest than open or developed land, mixed and deciduous forest, or wetland. A persistent use of shrub-dominated cover by vireo fledglings suggests this land-cover type provides analogous resources to those used by adults during the breeding season. This habitat use pattern is supported by hypotheses of postfledging habitat use (e.g., food search and breeding site selection).

Fig. 3. Predicted relationship between distance $(\mathrm{m})$ of fledgling Black-capped Vireo (Vireo atricapilla) to woodland cover and day of the postfledging season in 2013 and 2014 at Balcones Canyonlands National Wildlife Refuge and surrounding private properties. The relationship was determined using generalized additive mixed model selection and predicts that fledglings are located $10 \mathrm{~m}$ closer to woodland for every 10 -d progression in the postfledging season. Black line $=$ mean, gray $=95 \%$ confidence intervals.

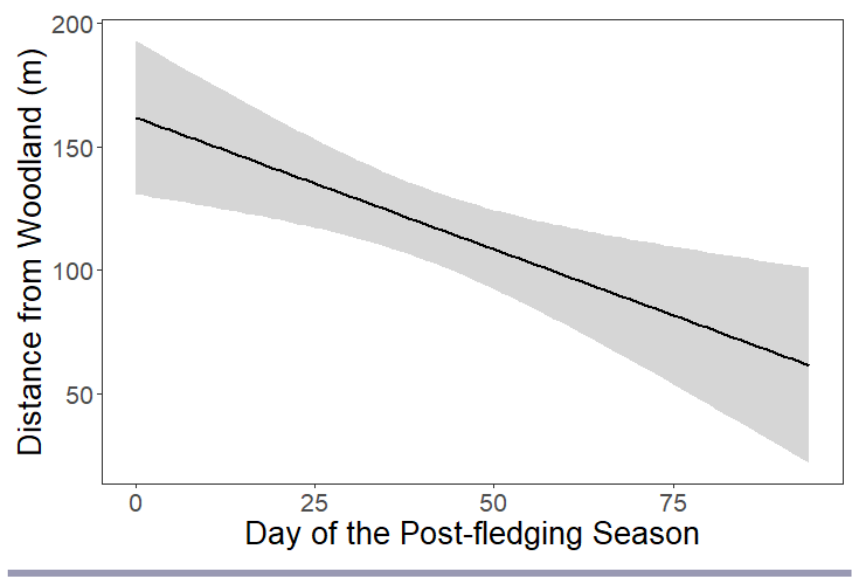

Fledglings will disperse from their natal areas to look for available food resources and familiarize themselves with feeding sites to use in future nesting seasons (i.e., food search hypothesis; Eden 1987). At our study sites, the canopy and shrub layers of the shrubdominated cover primarily comprised Ashe juniper, shin oak, or live oak, which are common vireo foraging substrates in central Texas (Houston 2008, Morgan 2012). Additionally, the vegetation composition of our study area was similar to that of Dittmar et al.'s (2014) study area in central Texas, where they found higher arthropod abundance in shrubland than in forest. Despite seasonal fluctuations in arthropod systems observed in central Texas (Quinn 2000, Morgan 2012, Marshall et al. 2013), Dittmar et al. (2014) did not find any seasonal trends in arthropod abundance in shrub or forest vegetation. Therefore, shrubdominated cover may provide adequate food resources for fledglings throughout the postfledging season.

Fledglings explore habitat prior to migration to prospect for future breeding locations (i.e., breeding site selection hypothesis; Morton et al. 1991). Vireos, like other migratory songbirds (Faaborg et al. 2010), exhibit strong site fidelity, with $60-70 \%$ annual returns in adult males (U.S. Fish and Wildlife Service 1991), although return rates for hatch-year vireos are not specified. Because vireos breed predominantly in early to midsuccessional vegetation, older fledglings may remain in shrubdominated cover to become familiar with potential nesting sites for future years (Walker 2015).

However, some young songbirds move out of the nesting habitat into other cover types, as documented in juvenile Ovenbird (Seiurus aurocapilla), which fledges from nests in late-successional 
woodland and uses regenerating clearcuts throughout the postfledging stage (Pagen et al. 2000, Marshall et al. 2003, Vitz and Rodewald 2007). Vireo postfledging use of non-nesting cover types is documented throughout its range and warrants further exploration. We observed young fledgings from shrubland-cover and woodland-cover nests using woodland cover. Postfledging use of woodland was best explained by time of season, although a $15 \%$ increase in the predicted probability of woodland use over the season may not be biologically significant for this species.

We observed fledglings moving toward the shrubland-woodland interface over time and found that this pattern was best explained by fledgling age and time of season. In our study, the increase in proximity to woodland was not a consequence of more detections of old fledglings in woodland during the late period of the postfledging season, indicated by the low weights of the models containing the interaction of age and season. Nor was the increase attributable to more nests at the end of the season located closer to woodland $\left(F_{1,127}=2.14, P=0.15\right)$. Instead, older fledglings may have occupied these areas the most, at least in part, because they are more mobile (Graber 1961). As fledglings age and disperse from their natal territories, they are likely to reach other vegetation types such as woodlands and ravines, and may stay there (Dittmar et al. 2014). Whether fledglings move toward woodland cover or simply move away from the natal territory could be further explored via radio-telemetry techniques to track distances from the nest over the entire postfledging period.

Moreover, fledglings disperse from the natal area to flock, socialize, and migrate with conspecifics (i.e., socialization hypothesis; Hamilton 1971, Powell 1974). Golden-winged Warbler (Vermivora chrysoptera) fledglings from nests in shrubland cover move toward the nearest forest-shrubland edge in the first week postfledging, presumably under the direction of adults guiding fledglings to forested areas (Streby et al. 2016). Adult vireos have been observed breeding (Pope et al. 2013) and foraging (Morgan 2012) in deciduous and oak-juniper woodlands of central Texas and may move toward forest edges during postbreeding, as observed in adult wood thrushes (Rappole and Ballard 1987, Vega Rivera et al. 1998). Adult vireos that move toward and into the woodland at the end of the breeding season maybe followed by fledgling vireos relying on conspecific cues crucial for survival.

Most postfledging survival studies propose that fledgling survival is indirectly related to habitat quality, and management addressing postfledging habitat can improve survivorship (Cox et al. 2014, Naef-Daenzer and Grüebler 2016). For example Ovenbird fledglings select habitat with greater vegetation complexity that offers protection from predation (i.e., predatoravoidance hypothesis; King et al. 2006), which is the primary cause of mortality for young altricial birds (Cox et al. 2014, NaefDaenzer and Grüebler 2016). Multiple vegetative strata, characteristic of woodlands, provide protective cover for independent fledglings that forage at various vegetation heights (Houston 2008). As shrub-dominated cover continues to decline from natural and anthropogenic causes across the vireo's breeding range, fledglings may need to rely on other land-cover types that provide vegetation-specific resources to survive. For instance, postfledging survival of Wood Thrush in Indiana was not affected by nest vegetation structure but was negatively affected by the interaction of low mature forest cover and drought (Vernasco et al. 2018). Although we did not directly examine fledgling survival, we propose that future studies measure the weekly survival of marked fledglings from territories characterized by different vegetation and land-cover characteristics to assess the various hypotheses presented. Additional research on the effects of broadscale features on postfledging habitat use and survival would be helpful to discriminate between the hypotheses of postfledging habitat use and improve the understanding and management of this critical lifestage.

\section{Management implications}

The Black-capped Vireo was delisted from the Federal List of Endangered and Threatened Wildlife on April 16, 2018 due to recovery. This action increases the importance for private landowners to know and implement sound habitat management strategies for the species' persistence. Areas with shrub-dominated cover are already recognized as optimal breeding habitat for adult vireos, but these areas should also be recognized as habitat for young during the postfledging season. We observed that older fledglings use woodland areas and fledglings moved closer to the woodland over time. Therefore, land managers should recognize woodlands adjacent to shrublands as potential habitat for vireo fledglings. These areas may include mature oak-juniper woodlands, which the federally endangered Golden-cheeked Warbler (Setophaga chrysoparia) inhabits, where it occasionally overlaps with vireos (Pulich 1976; M. Martinez, unpublished data). We recommend creating or maintaining heterogeneity in the vegetation structure and composition. A diversity of woody species at a variety of heights should promote foraging opportunities within and between seasons while providing protective cover from predators. Management activities on Balcones Canyonlands National Wildlife Refuge and surrounding private land include cattle grazing, prescribed burning, and mechanical treatments (e.g., flat cut, dozer, masticator, and shaded fuel break) to maintain the early successional, homogeneous vegetation favored by vireos. However, we recommend avoiding any extensive vegetative manipulation that would modify or remove vegetation in shrubdominated and woodland cover, such as the aforementioned activities, until the end of the postfledging season (i.e., August), to maintain habitat for fledglings.

Responses to this article can be read online at: http://www.ace-eco.org/issues/responses.php/1300

\section{Acknowledgments:}

We thank all our field technicians for their diligence and hard work. We express our gratitude to the staff at the Balcones Canyonlands National Wildlife Refuge for providing housing and property access, as well as to all the private landowners for permitting research activities on their properties. Additionally, we thank the Texas A\&M Natural Resources Institute and T. McFarland for logistical support. This work was funded by the Joint Fire Science Program, Bureau of Land Management, and Braun \& Gresham, PLLC, Texas EcoLab. We thank several anonymous reviewers for constructive comments. 


\section{LITERATURE CITED}

Anders, A. D., J. Faaborg, and F. R. Thompson III. 1998. Postfledging dispersal, habitat use, and home-range size of juvenile wood thrushes. Auk 115:349-358. http://dx.doi.org/10.2307/4089193

Barg, J. J., J. Jones, and R. J. Robertson. 2005. Describing breeding territories of migratory passerines: suggestions for sampling, choice of estimator, and delineation of core areas. Journal of Animal Ecology 74:139-149. http://dx.doi.org/10.1111/j.1365-2656.2004.00906. $\mathrm{x}$

Bates, D., M. Maechler, B. Bolker, and S. Walker. 2015. Fitting linear mixed-effects models using lme4. Journal of Statistical Software 67:1-48. http://doi.org/10.18637/jss.v067.i01

Brokaw, N. V., and R. A. Lent. 1999. Vertical structure. Pages 373-399 in M. L. Hunter Jr., editor. Maintaining biodiversity in forest ecosystems. Cambridge University Press, Cambridge, UK. http:// dx.doi.org/10.1017/CBO9780511613029.013

Burnham, K. P., and D. R. Anderson. 2002. Model selection and multimodel inference: a practical information-theoretic approach. Second edition. Springer Science, New York, New York, USA

Cherry, S. 1996. A comparison of confidence interval methods for habitat use-availability studies. Journal of Wildlife Management 60:653-658. http://dx.doi.org/10.2307/3802084

Cox, W. A., F. R. Thompson III, A. S. Cox, and J. Faaborg. 2014. Post-fledging survival in passerine birds and the value of postfledging studies to conservation. Journal of Wildlife Management 78:183-193. http://dx.doi.org/10.1002/jwmg.670

Diamond, D. D. 1997. An old-growth definition for western juniper woodlands: Texas ash juniper dominated or codominated communities. Report SRS-15. U.S. Department of Agriculture Forest Service, Southern Research Station, Asheville, North Carolina, USA. http://dx.doi.org/10.2737/SRS-GTR-15

Dittmar, E. M., D. A. Cimprich, J. H. Sperry, and P. J. Weatherhead. 2014. Habitat selection by juvenile black-capped vireos following independence from parental care. Journal of Wildlife Management 78:1005-1011. http://dx.doi.org/10.1002/jwmg.738

Eden, D. F. 1987. Natal philopatry of the magpie Pica pica. Ibis 129:477-490. http://dx.doi.org/10.1111/j.1474-919X.1987.tb08235. $\mathrm{x}$

Elliott, L. F., D. D. Diamond, C. D. True, C. F. Blodgett, D. Pursell, D. German, and A. Treuer-Kuehn. 2014. Ecological mapping systems of Texas: summary report. Texas Parks and Wildlife Department, Austin, Texas, USA.

Environmental Systems Research Institute (ESRI). 2010. ArcGIS release 10.0. Redlands, California, USA.

Faaborg, J., R. T. Holmes, A. D. Anders, K. L. Bildstein, K. M. Dugger, S. A. Gauthreaux Jr., P. Heglund, K. A. Hobson, A. E. Jahn, D. H. Johnson, S. C. Latta, D. J. Levey, P. P. Marra, C. L. Merkord, E. Nol, S. I. Rothstein, T. W. Sherry, T. S. Sillett, F. R. Thompson III, and N. Warnock. 2010. Recent advances in understanding migration systems of New World land birds. Ecological Monographs 80:3-48. http://dx.doi.org/10.1890/09-0395.1

Gehlbach, F. R. 1988. Forests and woodlands of the northeastern Balcones escarpment. Pages 57-77 in B. B. Amos and F. R. Gehlbach, editors. Edwards Plateau vegetation: plant ecological studies in central Texas. Baylor University Press, Waco, Texas, USA.

Graber, J. W. 1961. Distribution, habitat requirements, and life history of the black-capped vireo (Vireo atricapilla). Ecological Monographs 31:313-336. http://dx.doi.org/10.2307/1950756

Grzybowski, J. A. 1995. Black-capped vireo: Vireo atricapillus, version 2.0. In A. F. Poole and F. B. Gill, editors. The Birds of North America. Cornell Lab of Ornithology, Ithaca, New York, USA. https://doi.org/10.2173/bna.181

Guisan, A., T. C. Edwards Jr., and T. Hastie. 2002. Generalized linear and generalized additive models in studies of species distributions: setting the scene. Ecological Modeling 157:89-100. http://dx.doi.org/10.1016/S0304-3800(02)00204-1

Hamilton, W. D. 1971. Geometry for the selfish herd. Journal of Theoretical Biology 31:295-311. http://dx.doi.org/10.1016/0022-5193 (71)90189-5

Hartig, F. 2018. DHARMa: residual diagnostics for hierarchical (multi-level/mixed) regression models. $\mathrm{R}$ package version 0.1.6. [online] URL: http://florianhartig.github.io/DHARMa/

Hastie, T. J., and R. J. Tibshirani. 1986. Generalized additive models. Statistical Science 1:314-318. http://dx.doi.org/10.1214/ss/1177013609

Hastie, T. J., and R. J. Tibshirani. 1990. Generalized additive models. Chapman and Hall, London, UK. http://dx.doi.org/10.21236/ ADA147454

Horning, N. 2004. Justification for using photo interpretation methods to interpret satellite imagery: version 1.0. American Museum of Natural History, Center for Biodiversity and Conservation, New York, New York, USA. [online] URL: http:// biodiversityinformatics.amnh.org

Houston, D. R. 2008. Foraging behavior of the black-capped vireo in central Texas. Thesis. Texas State University, San Marcos, Texas, USA.

King, D. I., R. M. Degraaf, M. L. Smith, and J. P. Buonaccors. 2006. Habitat selection and habitat-specific survival of fledgling ovenbirds (Seiurus aurocapilla). Journal of Zoology 269:414-421. http://dx.doi. org/10.1111/j.1469-7998.2006.00158.x

Marshall, M. R., J. A. DeCecco, A. B. Williams, G. A. Gale, and R. J. Cooper. 2003. Use of regenerating clearcuts by late-successional bird species and their young during the post-fledging period. Forest Ecology and Management 183:127-135. http://dx.doi.org/10.1016/ S0378-1127(03)00101-4

Marshall, M., M. L. Morrison, and N. R. Wilkins. 2013. Tree species composition and food availability affect productivity of an endangered species: the golden-cheeked warbler. Condor 115:882-892. http://dx.doi.org/10.1525/cond.2013.130013

McFadden, D. 1974. Conditional logit analysis of qualitative choice behavior. Pages 105-142 in P. Zarembka, editor. Frontiers in econometrics. Academic Press, New York, New York, USA. [online] URL: https://eml.berkeley.edu/reprints/mcfadden/zarembka.pdf

Moore, F. R., S. A. Gauthreaux Jr., P. Kerlinger, and T. R. Simons. 1993. Stopover habitat: management implications and guidelines. Pages 58-69 in D. M. Finch and P. W. Stangel, editors. Status and 
management of Neotropical migratory birds. U.S. Forest Service General Technical Report RM-229. U.S. Forest Service, Fort Collins, Colorado, USA.

Morgan, D. 2012. Foraging ecology and forage availability for the black-capped vireo (Vireo atricapilla). Dissertation. Texas State University, San Marcos, Texas, USA.

Morton, M. L., M. W. Wakamatsu, M. E. Pereyra, and G. A. Morton. 1991. Postfledging dispersal, habitat imprinting, and philopatry in a montane, migratory sparrow. Ornis Scandinavia 22:98-106. http://dx.doi.org/10.2307/3676540

Naef-Daenzer, B., and M. U. Grüebler. 2016. Post-fledging survival of altricial birds: ecological determinants and adaptation. Journal of Field Ornithology 87:227-250. http://dx.doi.org/10.1111/ jofo. 12157

National Climate Data Center. 2014. Climate at a glance. National Oceanic and Atmospheric Administration, Asheville, North Carolina, USA. [online] URL: http://www.ncdc.noaa.gov/cag/

Neu, C. W., C. R. Byers, J. M. Peek, and V. Boy. 1974. A technique for analysis of utilization-availability data. Journal of Wildlife Management 38:541-545. http://dx.doi.org/10.2307/3800887

Pagen, R. W., F. R. Thompson III, and D. E. Burhans. 2000. Breeding and post-breeding habitat use by forest migrant songbirds in the Missouri Ozarks. Condor 102:738-747. http://dx.doi. org/10.1650/0010-5422(2000)102[0738:BAPBHU]2.0.CO;2

Pope, T. L., T. J. Conkling, K. N. Smith, M. R. Colon, M. L. Morrison, and R. N. Wilkins. 2013. Woodlands as quality breeding habitat for black-capped vireos. Journal of Wildlife Management 775:994-1001. http://dx.doi.org/10.1002/jwmg.539

Powell, G. V. N. 1974. Experimental analysis of the social value of flocking by starlings (Sturnus vulgaris) in relation to predation and foraging. Animal Behaviour 22:501-505. http://dx.doi.org/10.1016/ S0003-3472(74)80049-7

Pulich, W. M. 1976. The golden-cheeked warbler: a bioecological study. Texas Parks and Wildlife Department, Austin, Texas, USA.

Quinn, M. A. 2000. Abundance and distribution of potential arthropod prey species in a typical golden-cheeked warbler habitat. Thesis. Texas A\&M University, College Station, Texas, USA.

R Core Team. 2018. R: a language and environment for statistical computing. R Foundation for Statistical Computing, Vienna, Austria. [online] URL: https://www.R-project.org/

Rappole, J. H., and K. Ballard. 1987. Postbreeding movements of selected species of birds in Athens, Georgia. Wilson Bulletin 99:475-480.

Sellards, E. H., W. S. Adkins, and F. B. Plummer. 1933. The geology of Texas: volume 1: stratigraphy. University of Texas Bulletin 3232: August 22, 1932. [online] URL: https://repositories.lib.utexas.edu/ bitstream/handle/2152/24040/UT-bulletin-no3232.pdf?

sequence $=2 \&$ is Allowed $=y$
Streby, H. M., and D. E. Andersen. 2011. Seasonal productivity in a population of migratory songbirds: why nest data are not enough. Ecosphere 2:art78. http://dx.doi.org/10.1890/ES10-00187.1

Streby, H. M., and D. E. Andersen. 2013. Movements, cover-type selection, and survival of fledgling ovenbirds in managed deciduous and mixed coniferous-deciduous forests. Forest Ecology and Management 287:9-16. http://dx.doi.org/10.1016/j.foreco.2012.08.046

Streby, H. M., S. M. Peterson, and D. E. Andersen. 2016. Goldenwinged warbler fledgling habitat use and survival in the western Great Lakes region. Pages 127-140 in H. M. Streby, D. E. Andersen, and D. A. Buehler, editors. Golden-winged warbler ecology, conservation, and habitat management. CRC Press, Boca Raton, Florida, USA.

Sugiura, N. 1978. Further analysis of the data by Akaike's information criterion and the finite corrections. Communications in Statistics: Theory and Methods 7:13-26. http://dx.doi. org/10.1080/03610927808827599

U.S. Fish and Wildlife Service. 1991. Black-capped vireo (Vireo atricapillus) recovery plan. U.S. Fish and Wildlife Service, Austin, Texas, USA.

Vega Rivera, J. H., J. H. Rappole, W. J. McShea, and C. A. Haas. 1998. Wood thrush postfledging movements and habitat use in northern Virginia. Condor 100:69-78. http://dx.doi.org/10.2307/1369898

Vernasco, B. J., T. S. Sillett, P. P. Marra, and T. B. Ryder. 2018. Environmental predictors of nestling condition, postfledging movement, and postfledging survival in a migratory songbird, the wood thrush (Hylocichla mustelina). Auk 135:15-24. http://dx.doi. org/10.1642/AUK-17-105.1

Vitz, A. C., and A. D. Rodewald. 2007. Vegetative and fruit resources as determinants of habitat use by mature-forest birds during the postbreeding period. Auk 124:494-507. http://dx.doi.org/10.1642/0004-8038 (2007)124[494:VAFRAD]2.0.CO;2

Walker, L. E. 2015. Population dynamics of the endangered blackcapped vireo (Vireo atricapilla). Dissertation. University of Washington, Seattle, Washington, USA.

White, J. D., T. Gardali, F. R. Thompson III, and J. Faaborg. 2005. Resource selection by juvenile Swainson's thrushes during the postfledging period. Condor 107:388-401. http://dx.doi.org/10.1650/7606

Wood, S. N. 2006. Generalized additive models: an introduction with $R$. Chapman and Hall and CRC Press, Boca Raton, Florida, USA.

Zuur, A. F. 2016. A beginner's guide to generalized additive models with $R$. Highland Statistics, Newburgh, UK.

Zuur, A. F., E. N. Ieno, N. J. Walker, A. A. Saveliev, and G. M. Smith. 2013. Mixed effects models and extensions in ecology with $R$. Springer, New York, New York, USA. http://dx.doi. org/10.1007/978-0-387-87458-6

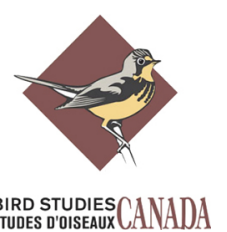

